\title{
EXPIRED DRUGS AS INHIBITORS IN ELECTROCHEMICAL PROCESSES - A MINI-REVIEW
}

\author{
NICOLAE VASZILCSIN ${ }^{\mathrm{a}}$, DELIA-ANDRADA DUCA ${ }^{\mathrm{a}, *}$, \\ ADRIANA FLUERAŞ ${ }^{a}$, MIRCEA-LAURENTTIU DAN $^{a}$
}

\begin{abstract}
Inhibitors of electrochemical processes have useful applications in corrosion protection of metals and alloys, as well as in galvanotechnics as levellers for the cathodic metal deposition. Active substances of drugs are good inhibitors, taking into account that they have in their molecules structures containing $\pi$ electrons or lone pair electrons, being able to adsorb on the metal surfaces through weak physical or strong chemical interactions. Significant inhibition efficiency of several drugs have been proved many years ago, but unfortunately, drugs are expensive and their practical applications as corrosion inhibitors for metal and alloys has been delayed. In the present papers, the studies on the inhibition properties in metal corrosion processes of expired drugs have been emphasized, starting with the paper of R. S. Abdel Hameed, published in 2009. There are few studies on the expired drugs used as levellers in the cathodic metal deposition.
\end{abstract}

Keywords: expired drugs, corrosion inhibitors, inhibition efficiency, galvanic levellers

\section{INTRODUCTION}

In the most applied electrochemical processes the enhancement of the useful reaction is the major aim, having as a result a decrease of the electrode overpotential. In this respect, a conclusive example is given by water electrolysis in which the diminution of hydrogen, respectively oxygen evolution overpotential leads to an optimized voltage cell close to the difference between reversible potentials of oxygen and hydrogen evolution reactions. Consequently, the energy yield is maximized [1]. Similar situations are encountered in sodium chloride solution electrolysis, as well as in the electrode processes occurring in fuel cells $[2,3]$.

\footnotetext{
a University Politehnica Timişoara, Faculty of Industrial Chemistry and Environmental Engineering, Timişoara, Romania

*Corresponding author: duca.delia@gmail.ro
} 
On the other hand, there are several cases in which an inhibition of electrode process is useful. The most compelling example is the corrosion of metals and their alloys. The decrease of the corrosion rate, for example in aggressive aqueous solutions, can be realized by the inhibition of the anodic metal ionization or/and cathodic hydrogen evolution or oxygen reduction reaction.

A special situation is encountered in galvanotechnics, more exactly in the metal electrodeposition, in which the quality of the deposited layer (adhesion, decorative aspect, compactness) is more important than the energy yield.

The study of the drugs inhibiting properties has been stimulated by the huge amount of expired or unused medicines. A part of them are destroyed by incineration, but an important amount is released in the residual water, thus polluting the environment $[4,5]$. Furthermore, drugs neutralization by incineration endangers the atmosphere with toxic compounds containing nitrogen, sulphur, phosphorus, fluorine and chlorine. On the other hand, the researches of the corrosion inhibitory properties of expired drugs are sustained by the report of US Food and Drug Administration that showed $90 \%$ of the massive drug stock of the US Army maintained their characteristics long time after the expiration dates [6].

Active substances from medicines have been intensively studied taking into account that in their molecules there are structures that facilitate physical or chemical interactions with metals: aromatic rings, multiple bonds, $\mathrm{N}, \mathrm{O}$ or $\mathrm{S}$ atoms containing lone pair electrons $[7,8]$. An elaborate review on the drugs corrosion inhibitory effect on metals and alloys in various media has been published by G. Gece [9], while D. S. Chauhan et al. have summarized the results on expired drugs as novel corrosion inhibitors published up to 2016 [10].

\section{EXPIRED DRUGS AS CORROSION INHIBITORS}

By our knowledge, the study of expired drugs as corrosion inhibitor has been started by R. S. Abdel Hameed, in 2009, when he used expired Ranitidine (active substance: ranitidine hydrochloride) as corrosion inhibitors for aluminum in hydrochloric acid solutions [11,12].

Further, the research of unused drugs has been focused on corrosion inhibition of carbon steel in various aggressive media. Expired Carbamazepine and Paracetamol have been used as inhibitors for carbon steel in $0.1 \mathrm{M}$ sulfuric acid solution, as well as in acetic acid/sodium acetate buffer solution [6]. Studies on the corrosion inhibition capacity of Citicoline, Carbocisteine and 
Paracetamol, in $1 \mathrm{M}$ hydrochloric acid, have been carried out by F. H. Ali et al [13]. Expired Declophen (active substance: diclofenac sodium) was evaluated by R. S. Abdel Hameed as non-toxic corrosion inhibitor for carbon steel in $1 \mathrm{M}$ hydrochloric acid [14]. In the same medium, excellent results have been obtained by N. K. Gupta et al. in their investigation on the corrosion inhibition of carbon steel using expired Atenolol and Nifedipine [15]. Similar results have been obtained by P. Dohare, using expired Tramadol (active substance: tramadol hydrochloride) [16], as well as, A. K. Singh et al. using semi synthetic antibiotic Cefdinir [17]. Inhibition efficiencies up to $90 \%$ have been reported by R. S. Abdel Hameed for expired Ranitidine [18]. Recently, R. A. Anaee et al. have reported the effect of expired Etoricoxib on the corrosion rate of carbon steel in $0.5 \mathrm{M} \mathrm{H}_{3} \mathrm{PO}_{4}$ solution, at $30^{\circ}$ and $60^{\circ} \mathrm{C}$ [19]. In $\mathrm{HCl}$ solution, expired Citicoline, Carbocisteine and Paracetamol have been tested [13], while in neutral media, expired Fluconazole has been evaluated [20].

Weight loss measurement was a proper technique used in order to determine the inhibition efficiency (IE), defined by the equation (1) and expressed in \% [21]:

$$
I E=\frac{W-W_{i n h}}{W} \cdot 100
$$

where $W$ and $W_{\text {inh }}$ are the corrosion rate in the absence, respectively presence of the drug, $\mathrm{mg} \mathrm{dm}^{-2} \mathrm{~h}^{-1}$.

Table 1 emphasizes inhibition efficiencies IE [\%], obtained by different authors, using weight loss measurements.

In order to determine the inhibition efficiency many researchers prefer Tafel slope method based on the equation (2) [27]:

$$
I E=\frac{i_{\text {corr }}-i_{\text {corr }(i n h)}}{i_{\text {corr }}} \cdot 100
$$

where $i_{\text {corr }}$ and $i_{\text {corr(inh) }}$ are corrosion current densities in the absence, respectively presence of the inhibitor, $\mathrm{A} \mathrm{m}^{-2}$.

It has to be mentioned that IE computed using weight loss measurements represents an average value during the test time, while IE determined by Tafel slope method is an instantaneous one. Also, instantaneous inhibition efficiency is obtained using electrochemical impedance spectroscopy (EIS) based on equation (3) [28, 29]:

$$
I E=\frac{R_{c t(i n h)}-R_{c t}}{R_{c t(i n h)}} \cdot 100
$$

where $R_{\mathrm{ct}}$ and $R_{\mathrm{ct}(\mathrm{inh})}$ are charge transfer resistance in the absence and presence of the inhibitor, $\Omega \mathrm{m}^{2}$. 
Table 1. Inhibition efficiency of expired drugs for carbon steel in $1 \mathrm{M} \mathrm{HCl}$ (weight loss method).

\begin{tabular}{|c|c|c|c|c|}
\hline Expired drug & $\begin{array}{c}\text { Drug } \\
\text { concentration }\end{array}$ & IE [\%] & References & Remarks \\
\hline \multirow{2}{*}{ Citicoline } & $0.008 \mathrm{M}$ & 28 & \multirow{2}{*}{ [13] } & \multirow{2}{*}{$\begin{array}{c}\text { Test time: } 24 \mathrm{~h} \\
\text { Ambient temperature }\end{array}$} \\
\hline & $0.012 \mathrm{M}$ & 25 & & \\
\hline \multirow{5}{*}{ Paracetamol } & $0.003 \mathrm{M}$ & 83 & \multirow{5}{*}{ [13] } & \multirow{5}{*}{$\begin{array}{c}\text { Test time: } 24 \mathrm{~h} \\
\text { Ambient temperature }\end{array}$} \\
\hline & $0.006 \mathrm{M}$ & 77 & & \\
\hline & $0.009 \mathrm{M}$ & 80 & & \\
\hline & $0.012 \mathrm{M}$ & 87 & & \\
\hline & $0.017 \mathrm{M}$ & 88 & & \\
\hline \multirow{4}{*}{ Carbocisteine } & $0.0055 \mathrm{M}$ & 54 & \multirow{4}{*}{ [13] } & \multirow{4}{*}{$\begin{array}{c}\text { Test time: } 24 \mathrm{~h} \\
\text { Ambient temperature }\end{array}$} \\
\hline & $0.016 \mathrm{M}$ & 14 & & \\
\hline & $0.021 \mathrm{M}$ & 65 & & \\
\hline & $0.030 \mathrm{M}$ & 75 & & \\
\hline \multirow{5}{*}{ Declophen } & $0.5 \%$ & 69 & \multirow{5}{*}{ [14] } & \multirow{5}{*}{$\begin{array}{c}\text { Test time: } 168 \mathrm{~h} \\
\mathrm{~T}=303 \mathrm{~K}\end{array}$} \\
\hline & $1.0 \%$ & 70 & & \\
\hline & $1.5 \%$ & 75 & & \\
\hline & $2.0 \%$ & 80 & & \\
\hline & $2.5 \%$ & 87 & & \\
\hline \multirow{5}{*}{ Ranitidine } & $50 \mathrm{ppm}$ & 61 & \multirow{5}{*}{ [18] } & \multirow{5}{*}{$\begin{array}{c}\text { Test time: } 168 \mathrm{~h} \\
T=303 \mathrm{~K}\end{array}$} \\
\hline & 100 ppm & 65 & & \\
\hline & $150 \mathrm{ppm}$ & 75 & & \\
\hline & $250 \mathrm{ppm}$ & 81 & & \\
\hline & $400 \mathrm{ppm}$ & 89 & & \\
\hline \multirow{4}{*}{ Tramadol } & $25 \mathrm{mg} \mathrm{L}-1$ & 83 & \multirow{4}{*}{ [16] } & \multirow{4}{*}{$\begin{array}{c}\text { Test time: } 3 \mathrm{~h} \\
\text { Ambient temperature }\end{array}$} \\
\hline & $50 \mathrm{mg} \mathrm{L}-1$ & 91 & & \\
\hline & $75 \mathrm{mg} \mathrm{L}-1$ & 94 & & \\
\hline & $100 \mathrm{mg} \mathrm{L}-1$ & 96 & & \\
\hline \multirow{6}{*}{ Cefdinir } & $0.63 \cdot 10-4 \mathrm{M}$ & 75 & \multirow{6}{*}{ [17] } & \multirow{6}{*}{$\begin{array}{l}\text { Test time: } 3 \mathrm{~h} \\
T=308 \mathrm{~K}\end{array}$} \\
\hline & $1.26 \cdot 10-4 \mathrm{M}$ & 82 & & \\
\hline & $2.52 \cdot 10-4 \mathrm{M}$ & 85 & & \\
\hline & $3.79 \cdot 10-4 \mathrm{M}$ & 92 & & \\
\hline & $5.05 \cdot 10-4 \mathrm{M}$ & 95 & & \\
\hline & $6.32 \cdot 10-4 \mathrm{M}$ & 96 & & \\
\hline Gentamicin & $0.9 \%$ & 92 & [22] & $\begin{array}{c}\text { Test time: } 6 \mathrm{~h} \\
T=303 \mathrm{~K}\end{array}$ \\
\hline Carvedilol & $1.6 \cdot 10^{-4} \mathrm{M}$ & 99 & [23] & $\begin{array}{c}\text { Test time: } 30 \mathrm{~min} \\
T=298 \mathrm{~K}\end{array}$ \\
\hline Ambroxol & $9 \%$ & 94 & [24] & $\begin{array}{c}\text { Test time: } 4 \mathrm{~h} \\
\text { Ambient temperature }\end{array}$ \\
\hline Pantoprazol & 300 ppm & 93 & [25] & $\begin{array}{c}\text { Test time: } 2 \mathrm{~h} \\
T=303 \mathrm{~K}\end{array}$ \\
\hline Phenytoin & 500 ppm & 70 & [26] & $\begin{array}{c}\text { Test time: } 72 \mathrm{~h} \\
T=298 \mathrm{~K}\end{array}$ \\
\hline
\end{tabular}


Corrosion efficiencies for carbon steel obtained by Tafel slope method and EIS are given in table 2.

Table 2. Inhibition efficiency of expired drugs for carbon steel

(Tafel slope method and EIS).

\begin{tabular}{|c|c|c|c|c|c|}
\hline Expired drug & $\begin{array}{c}\text { Drug } \\
\text { concentration }\end{array}$ & $\begin{array}{c}\text { Corrosive } \\
\text { medium }\end{array}$ & $\begin{array}{c}\text { Tafel IE } \\
{[\%]}\end{array}$ & $\begin{array}{c}\text { EIS IE } \\
{[\%]}\end{array}$ & References \\
\hline Atenolol & optimum value & $1 \mathrm{M} \mathrm{HCl}$ & 91 & 93 & [15] \\
\hline Nifedipine & optimum value & $1 \mathrm{M} \mathrm{HCl}$ & 93 & 96 & [15] \\
\hline Carbamazepine & $5 \cdot 10^{-3} \mathrm{M}$ & $0.1 \mathrm{M} \mathrm{H}_{2} \mathrm{SO}_{4}$ & 90 & - & [6] \\
\hline Paracetamol & saturated & $\begin{array}{c}\text { acetic acid } \\
0.25 \mathrm{M} / \text { sodium } \\
\text { acetate } 0.25 \mathrm{M}\end{array}$ & 85 & - & [6] \\
\hline \multirow{5}{*}{ Declophen } & $0.5 \%$ & \multirow{5}{*}{$1 \mathrm{M} \mathrm{HCl}$} & 64 & - & \multirow{5}{*}{ [14] } \\
\hline & $1.0 \%$ & & 68 & - & \\
\hline & $1.5 \%$ & & 74 & - & \\
\hline & $2.0 \%$ & & 78 & - & \\
\hline & $2.5 \%$ & & 88 & - & \\
\hline \multirow{5}{*}{ Ranitidine } & 50 ppm & \multirow{5}{*}{$1 \mathrm{M} \mathrm{HCl}$} & 62 & 60 & \multirow{5}{*}{ [18] } \\
\hline & 100 ppm & & 76 & 75 & \\
\hline & $150 \mathrm{ppm}$ & & 80 & 81 & \\
\hline & $250 \mathrm{ppm}$ & & 86 & 88 & \\
\hline & 400 ppm & & 90 & 92 & \\
\hline \multirow{10}{*}{ Etoricoxib } & $75 \mathrm{ppm}$ & \multirow{5}{*}{$\begin{array}{c}0.5 \mathrm{M} \mathrm{H}_{3} \mathrm{PO}_{4} \\
30^{\circ} \mathrm{C}\end{array}$} & 65 & - & \multirow{5}{*}{ [19] } \\
\hline & 125 ppm & & 58 & - & \\
\hline & $175 \mathrm{ppm}$ & & 70 & - & \\
\hline & $225 \mathrm{ppm}$ & & 81 & - & \\
\hline & $275 \mathrm{ppm}$ & & 68 & - & \\
\hline & $75 \mathrm{ppm}$ & \multirow{5}{*}{$\begin{array}{c}0.5 \mathrm{M} \mathrm{H}_{3} \mathrm{PO}_{4} \\
60^{\circ} \mathrm{C}\end{array}$} & 56 & - & \multirow{5}{*}{ [19] } \\
\hline & 125 ppm & & 64 & - & \\
\hline & $175 \mathrm{ppm}$ & & 54 & - & \\
\hline & 225 ppm & & 55 & - & \\
\hline & 275 ppm & & 60 & - & \\
\hline \multirow{6}{*}{ Cefdinir } & $0.63 \cdot 10-4 \mathrm{M}$ & \multirow{6}{*}{$\begin{array}{c}1 \mathrm{M} \mathrm{HCl} \\
35^{\circ} \mathrm{C}\end{array}$} & 75 & 81 & \multirow{6}{*}{ [17] } \\
\hline & $1.26 \cdot 10-4 \mathrm{M}$ & & 82 & 85 & \\
\hline & $2.52 \cdot 10-4 \mathrm{M}$ & & 85 & 87 & \\
\hline & $3.79 \cdot 10-4 \mathrm{M}$ & & 92 & 92 & \\
\hline & $5.05 \cdot 10-4 \mathrm{M}$ & & 95 & 97 & \\
\hline & $6.32 \cdot 10-4 \mathrm{M}$ & & 96 & 97 & \\
\hline \multirow[b]{2}{*}{ Paracetamol } & $10^{-3} \mathrm{M}$ & $0.1 \mathrm{M} \mathrm{H}_{2} \mathrm{SO}_{4}$ & 94 & 96 & \multirow{2}{*}{ [30] } \\
\hline & $10^{-3} \mathrm{M}$ & $1 \mathrm{M} \mathrm{HCl}$ & 86 & 85 & \\
\hline Clopidogrel & $250 \mathrm{ppm}$ & $2 \mathrm{M} \mathrm{HCl}$ & 93 & 86 & [31] \\
\hline Podocip & $100 \mathrm{mg} \mathrm{L}-1$ & $1 \mathrm{M} \mathrm{HCl}$ & 97.5 & 98 & [32] \\
\hline Doxelcalciferol & $0.4 \mathrm{~g} \mathrm{~L}-1$ & $3 \mathrm{M} \mathrm{HCl}$ & 87 & 89 & [33] \\
\hline
\end{tabular}


In order to improve the inhibitory activity a chemical modification of expired drugs has been reported. P. Singh et al. have used expired active substance of Dapsone modified with benzaldehyde and salicylaldehyde. Resulted Schiff bases were tested as corrosion inhibitors for carbon steel in aerated $0.5 \mathrm{M}$ sulphuric acid solution. Based on the gravimetric measurements, inhibition efficiencies of $96 \%$ and $94 \%$ have been obtained at an optimum concentration of $0.219 \mathrm{mM}$ Dapsone-benzaldehyde, respectively Dapsonesalicylaldehyde. An addition of about $0.6 \mathrm{mM} \mathrm{KCl}$ increased the inhibition efficiency up to $99 \%$ and $98 \%$ respectively [34]. Schiff bases derivate of expired antituberculosis drug Isoniazid were synthesized by A. K. Singh et al. using four 5-indol derivatives: 5-bromo-indole-3-carboxime, 5-chloro-indole-3-carboxime, 5-methoxy-indole-3-carboxime and indole-3-carboxime [35].

Very high inhibition efficiencies of expired Ethambutol (active substance: ethambutol hydrochloride) for mild steel in $0.5 \mathrm{M}$ hydrochloric acid have been obtained by S. Dahiya et al.: 99,60\% (weight loss), 99,35\% (Tafel plot method), 93,72\% (electrochemical impedance spectroscopy) [36].

$P$. Singh et al. have reported interesting results on the inhibition activity of fresh Atorvastatin (FA) and expired one (EA) (active substance: atorvastatin calcium). Both drugs have shown similar corrosion efficiency for mild steel in $1 \mathrm{M} \mathrm{HCl}$ with 150 ppm Atorvastatin: 98.4 and $99.1 \%$ (Tafel slope); 96.4 and $96.4 \%$ (electrochemical impedance), respectively 93.5 and 96.5\% (weight loss) [37].

Expired Cefpodoxime, Levofloxacin, Ofloxacin and Linezolid were tested for mild steel in $1 \mathrm{M} \mathrm{HCl}$. Generally, inhibition efficiencies over $90 \%$ have been obtained for $240 \mathrm{ppm}$ drug concentration in the aggressive solution [38]. In $5 \% \mathrm{HCl}$, using expired Varenicline, an inhibition efficiency of $78 \%$ has been reported for mild steel in weight loss test during $10 \mathrm{~h}$ and 0.4 $\mathrm{g} \mathrm{L}^{-1}$ drug [39]. Similar results have been registered in the case of Ceftin [40] and Amitriptyline expired drugs [41]. Raghavendra reported an inhibition efficiency up to $94 \%$ for mild steel in $3 \mathrm{M} \mathrm{HCl}$, in the presence of $0.2 \mathrm{mg} \mathrm{L}^{-1}$ expired Fluoxymesterone [42].

Generally, it is accepted that inhibitory activity of organic compounds on the metal corrosion is closely linked to the bond strength between organic molecule and metal. Information on such interactions is given by the adsorption Gibbs energy $\Delta G_{a d s}$. A value more negative than $-40 \mathrm{~kJ} \mathrm{~mol}^{-1}$ $\left(\Delta G_{a d s}<-40 \mathrm{~kJ} \mathrm{~mol}^{-1}\right)$ indicates that the interaction between organic substrate and metal is very strong and it is given by a chemical sorption, whereas a value more positive than $-20 \mathrm{~kJ} \mathrm{~mol}^{-1}\left(\Delta G_{a d s}>-20 \mathrm{~kJ} \mathrm{~mol}^{-1}\right)$ proves that the adsorption of inhibitor is physical [43]. Adsorption Gibbs energy depends on the equilibrium adsorption constant $K_{a d s}$, obtained based on the adsorption isotherms [44, 45]: 


$$
\Delta G_{a d s}=-2.303 R T \lg \left(55.5 \cdot K_{a d s}\right)
$$

Adsorption Gibbs energy values obtained for various expired drugs are given in table 3 , as well as the corresponding value of inhibitory efficiencies.

Data given in table 3 provide that higher inhibition efficiencies are obtained in the case of the chemical adsorption of expired drugs. The highest value of Gibbs energy $\left(-51 \mathrm{~kJ} \mathrm{~mol}^{-1}\right)$ was noticed by N. Raghavendra, for expired Lorazepam as an inhibitor for mild steel in $3 \mathrm{M} \mathrm{HCl} \mathrm{[46].}$

Table 3. Adsorption Gibbs energy and inhibitory efficiencies.

\begin{tabular}{|l|c|c|c|c|}
\hline \multicolumn{1}{|c|}{ Expired drug } & $\begin{array}{c}-\Delta \text { Gads } \\
{[\mathbf{k J} \text { mol-1] }}\end{array}$ & Temperature $[\mathbf{K}]$ & IE [\%] & References \\
\hline Ranitidine & 37 & $303 \mathrm{~K}$ & $90-92$ & {$[18]$} \\
\hline Declophen & 41 & $303 \mathrm{~K}$ & 88 & {$[14]$} \\
\hline Cefdinir & 39 & $308 \mathrm{~K}$ & $96-98$ & {$[17]$} \\
\hline Tramadol & 37 & $308 \mathrm{~K}$ & 96 & {$[16]$} \\
\hline $\begin{array}{l}\text { Isoniazid } \\
\text { derivatives }\end{array}$ & $35-39$ & & $91-96$ & {$[35]$} \\
\hline $\begin{array}{l}\text { Modified } \\
\text { Dapsone }\end{array}$ & $38-40$ & & $94-96$ & {$[34]$} \\
\hline Etoricoxib & 29 & $308 \mathrm{~K}$ & 92 & {$[19]$} \\
\hline Lorazepam & 51 & $333 \mathrm{~K}$ & 96 & {$[46]$} \\
\hline Amlodipine & 20.3 & $303 \mathrm{~K}$ & 84 & {$[47]$} \\
\cline { 2 - 4 } & 18.5 & $318 \mathrm{~K}$ & 69 & {$[48]$} \\
\hline Acetazolamide & 21 & $303 \mathrm{~K}$ & $86-96$ & \\
\hline
\end{tabular}

Activation energy $E_{a}$ is a general parameter that characterizes the rate of chemical or physical processes. Consequently, activation energy can emphasize the influence of inhibitors on the metal corrosion rate. The higher the activation energy in the presence of inhibitors, the better their inhibition efficiencies $[49,50]$. Activation energies for metal ionization in the absence and presence of the inhibitor, as well as the inhibitory efficiencies are given in Table 4. 
Table 4. Activation energies for metal ionization in the absence $E_{a}$ and presence of the inhibitor $E_{a(\text { inh })}$ and corresponding inhibition efficiencies.

\begin{tabular}{|l|c|c|c|c|c|}
\hline $\begin{array}{c}\text { Expired } \\
\text { drug }\end{array}$ & $\begin{array}{c}\mathbf{E}_{\mathbf{a}} \\
{\left[\mathbf{k J ~ m o l}^{-1}\right]}\end{array}$ & $\begin{array}{c}\boldsymbol{E}_{\mathbf{a}(\mathbf{i n h})} \\
{\left[\mathrm{kJ} \mathrm{mol}^{-1}\right]}\end{array}$ & $\begin{array}{c}\Delta \boldsymbol{E}_{\mathbf{a}} \\
{\left[\mathbf{k J ~ m o l}^{-1}\right]}\end{array}$ & IE [\%] & References \\
\hline Ranitidine & 40 & 55 & 15 & $90-92$ & {$[18]$} \\
\hline Declophen & 41 & 66 & 25 & 88 & {$[14]$} \\
\hline $\begin{array}{l}\text { Isoniazid } \\
\text { derivatives }\end{array}$ & 33 & $67-80$ & $34-47$ & $91-96$ & {$[35]$} \\
\hline Cefdinir & 42 & 99 & 57 & $96-98$ & {$[17]$} \\
\hline Pantoprazol & 26 & 47 & 21 & 93 & {$[25]$} \\
\hline Ambroxol & 61 & 41 & 20 & $61-65$ & {$[51]$} \\
\hline Clopidogrel & 82 & 94 & 12 & $83-93$ & {$[31]$} \\
\hline Ethambutol & 59 & 73 & 14 & $88-86$ & {$[52]$} \\
\hline
\end{tabular}

There are few studies related to the use of expired drugs as corrosion inhibitors for other metals than carbon steel. A. El-Aziz S. Fouda and A. M. El-Azaly have been studied the expired Concor as a potential non-toxic corrosion inhibitor for stainless steel (SS 304) in $\mathrm{HCl}$ solution. They have determined the inhibition efficiencies using weight loss measurements, Tafel slope method and electrochemical impedance spectroscopy. Weight loss procedure was applied for a few concentrations of the expired Concor drug between 50 and $300 \mathrm{ppm}$, in $2 \mathrm{M} \mathrm{HCl}$. The inhibition efficiencies were included in the range of $40-70 \%$. In the same aggressive medium, Tafel slope method gave inhibition activities between 36 and $64 \%$, while using electrochemical impedance spectroscopy inhibition efficiencies between 71 and $86 \%$ have been obtained [53].

$\mathrm{N}$. Raghavendra has reported the results obtained using expired Alprazolam as corrosion inhibitor for aluminum in $3 \mathrm{M}$ hydrochloric acid solution. Among current methods, a volumetric evaluation of the corrosion rate was applied, based on the volume of hydrogen evolved during the test. In this case, the inhibition efficiency is given by the relationship:

$$
I E=\frac{V_{H}-V_{H(i n h)}}{V_{H}} \cdot 100
$$

where $V_{H}$ and $V_{H(\text { inh) }}$ are the volume of hydrogen evolved during the corrosion test in the absence, respectively the presence of the inhibitor. 
Based on volumetric technique, inhibition efficiencies of $87 ; 92 ; 95$ and 98 have been obtained at $60^{\circ} \mathrm{C}$, during $2 \mathrm{~h}$, at following concentration of expired Alprazolam: $0.3 ; 0.6 ; 0.9$, respectively $1.2 \mathrm{~g} \mathrm{~L}^{-1}$. In the same conditions, electrochemical impedance spectroscopy gave efficiencies of 86; $95 ; 96$ and $97 \%$, while Tafel slope method gave about $99 \%$ for all drug concentrations [54].

Results obtained by M. M. Motawea et al. showed that expired Cidamex is good inhibitor for aluminum in $1 \mathrm{M} \mathrm{HCl}$. Inhibition efficiency reached $99.6 \%$ at 300 ppm Cidamex [55]. In $1 \mathrm{M} \mathrm{H}_{2} \mathrm{SO}_{4}$, with 400 ppm expired Betnesol (active substance: betamethasone sodium) or Moxifloxacin (active substance: moxifloxacin hydrochloride), inhibition efficiencies reached 94 $95 \%$, respectively $85-86 \%$ [56]. For the same metal and solution, K. R. Jahromi et al. have reported that, as corrosion inhibitor, expired Pantoprazol (active substance: pantoprazole) is less efficient than fresh Pantoprazol. For a drug concentration of $1500 \mathrm{ppm}$, electrochemical impedance inhibition efficiency decreased from 71 to $59 \%$, whereas Tafel slope one decreased from 71 to $51 \%$ [57]. Considerable efficiency for corrosion inhibition of aluminum was obtained using expired Voltaren (active substance: diclofenac sodium) (125 ppm in $1 \mathrm{M} \mathrm{HCl}$ ): $92 \%$ (Tafel slope) and 90\% (weight loss) [58].

The effect of expired Zosyn (active substances: piperacillin and tazobactam) on the corrosion rate of carbon steel in a standard $3.5 \% \mathrm{NaCl}$ solution was investigated by $\mathrm{M}$. Dan et al. Cyclic voltammograms drown on platinum in $\mathrm{NaCl}$ solution in the presence of Zosyn $10^{-3} \mathrm{M}\left(10^{-3} \mathrm{M}\right.$ is an apparent molar concentration consisting in $0.7 \cdot 10^{-3} \mathrm{M}$ Piperacillin and $0.3 \cdot 10^{-3} \mathrm{M}$ Tazobactam, taking into account that in Zosyn, the mass ratio Piperacillin/ Tazobactam is 4/1) proved that the drug is stable in the test solution in the potential range of $\pm 250 \mathrm{mV}$ versus open circuit potential. Corrosion studies have been carried out in the absence and presence of $10^{-6} ; 10^{-5} ; 10^{-4}$ and $10^{-3}$ M Zosyn. Inhibition efficiencies of $6 ; 11 ; 77$; respectively $79 \%$ have been obtained by Tafel plots method, at $298 \mathrm{~K}$, whereas gravimetric procedure, in the same circumstances, gave $10 ; 17 ; 72$; respectively $90 \%$ [59].

Ceftriaxone, the active substance of expired Cefort drug has been used as corrosion inhibitor for nickel in $0.5 \mathrm{M} \mathrm{H}_{2} \mathrm{SO}_{4}$ and $1 \mathrm{M} \mathrm{HCl}$. Electrochemical behavior of Ceftriaxone and its stability have been examined by cyclic voltammetry on platinum electrode. In the presence of Ceftriaxone, in both solutions, open circuit potential was shifted toward more positive potential. It has to be mentioned that the optimum concentration of Ceftriaxone is about $10^{-4} \mathrm{M}$ in $0.5 \mathrm{H}_{2} \mathrm{SO}_{4}$ and $10^{-5} \mathrm{M}$ in $1 \mathrm{M} \mathrm{HCl}$. Inhibition efficiencies have been determined by weight loss measurements (WLM), Tafel slope method (TSM) and electrochemical impedance spectroscopy (EIS) (Table 5) [60]. 
Table 5. Inhibition efficiencies in the presence of Ceftriaxone.

\begin{tabular}{|c|c|c|c|c|}
\hline Test & \multirow{2}{*}{$\begin{array}{c}\text { Ceftriaxone } \\
\text { solution }\end{array}$} & \multicolumn{3}{|c|}{ Inhibition efficiency [\%] } \\
\cline { 3 - 5 } concentration [M] & WLM & TSM & EIS \\
\hline $0.5 \mathrm{H}_{2} \mathrm{SO}_{4}$ & $10^{-4} \mathrm{M}$ & 71.4 & 70.1 & 69.5 \\
\hline $1 \mathrm{M} \mathrm{HCl}$ & $10^{-5} \mathrm{M}$ & 69.6 & 73.0 & 73.9 \\
\hline
\end{tabular}

For copper in $3 \mathrm{M} \mathrm{HCl}$, Narasimha Raghavendra et al. used expired Famotidine as corrosion inhibitor with an efficiency of $86 \%$ after a weight loss test during $4 \mathrm{~h}$, at $0.4 \mathrm{~g} \mathrm{~L}^{-1}$ drug concentration [61] and expired Naftifine (active substance: naftifine hydrochloride) in $5 \mathrm{M} \mathrm{HCl}$, with $69 \%$ efficiency in the same test conditions [62].

\section{EXPIRED DRUGS IN GALVANOTECHNICS}

The use of expired drugs as levelling agents is an accessible and cheap alternative to replace the commercial additives. So far there is few data about their use in galvanotechnics and further investigations are necessary. Expired Cefort (active substance: ceftriaxone) drug has been tested as levelling agent in copper and nickel electrodeposition $[63,64]$ and expired Midazolam and Caffeine in nickel electrodeposition $[65,66]$.

First, their electrochemical behavior has been studied by cyclic voltammetry on Pt electrode, in acid electrolyte solutions, similar with those used at industrial level, in which different concentrations of expired drugs have been added. For copper deposition, $0.5 \mathrm{~mol} \mathrm{~L}^{-1} \mathrm{H}_{2} \mathrm{SO}_{4}$ has been used, respectively $30 \mathrm{~g} \mathrm{~L}^{-1} \mathrm{H}_{3} \mathrm{BO}_{3}+0.5 \mathrm{~mol} \mathrm{~L}^{-1} \mathrm{Na}_{2} \mathrm{SO}_{4}$ for nickel electrodeposition. As a preliminary result, it was found that all drugs will not undergo degradation during the metal deposition.

Further, to determine the kinetic parameters of copper, respectively nickel electrodeposition by Taffel slope method, linear voltammograms (LVs) have been drawn in quasi stationary conditions, at low scan rate, on $\mathrm{Cu}$ or $\mathrm{Ni}$ electrode in electrolyte solutions containing $5 \mathrm{~g} \mathrm{~L}^{-1}$ metal ions in $0.5 \mathrm{~mol} \mathrm{~L}$ ${ }^{1} \mathrm{H}_{2} \mathrm{SO}_{4}$ for copper bath and in $30 \mathrm{~g} \mathrm{~L}^{-1} \mathrm{H}_{3} \mathrm{BO}_{3}$ for nickel bath, with addition of different concentrations of expired drugs. Based on LVs, Tafel plots were represented, from which the exchange current density $i_{0}$ and charge transfer coefficient 1- $\alpha$ have been calculated according to the Butler-Volmer equation applied in the range of high overpotentials [67].

$$
b=-\frac{2.303 R T}{(1-\alpha) z F}
$$




$$
a=\frac{2.303 R T}{(1-\alpha) z F} \lg i_{\mathrm{o}}
$$

where: $R$ is the gas constant, $\mathrm{J} \mathrm{mol}^{-1} \mathrm{~K}^{-1} ; T$ - thermodynamic temperature, $\mathrm{K}$; $1-\alpha$ - charge transfer coefficient; $z$ - elementary charge number; $F$ - Faraday constant, $\mathrm{C} \mathrm{mol}^{-1} ; i_{0}$ - exchange current density, $\mathrm{A} \mathrm{m}^{-2}$.

It has been reported that metal electrodeposition rate depends on the temperature, as well as the kinetic parameters (1- $\alpha)$ and $i_{0}$.

In table 6 , the obtained results for ceftriaxone used as additive in copper electrodeposition are presented [63]. Similar, in table 7, the results for ceftriaxone [64], midazolam [65] and caffeine [66] in nickel deposition process are shown.

Table 6. Kinetic parameters for copper electrodeposition on copper in electrolyte solution containing $0.5 \mathrm{~mol} \mathrm{~L}^{-1} \mathrm{H}_{2} \mathrm{SO}_{4}+5 \mathrm{~g} \mathrm{~L}^{-1} \mathrm{Cu}^{2+}$, with and without different concentrations of ceftriaxone.

\begin{tabular}{cccc}
\hline $\begin{array}{c}\text { Concentration } \\
{\left[\text { mol L-1 }^{-1}\right.}\end{array}$ & Temperature $\left[{ }^{\circ} \mathbf{C}\right]$ & $\mathbf{1 - \alpha}$ & $\boldsymbol{i}_{0}\left[\mathbf{A} \mathbf{~ m}^{-2}\right]$ \\
\hline & 25 & 0.16 & 8.90 \\
0 & 35 & 0.15 & 7.38 \\
& 45 & 0.22 & 4.38 \\
& 55 & 0.64 & 3.91 \\
& 65 & 0.46 & 3.24 \\
$10^{-6}$ & 25 & 0.21 & 11.10 \\
& 35 & 0.21 & 7.80 \\
& 45 & 0.32 & 7.25 \\
& 55 & 0.69 & 7.27 \\
$10^{-5}$ & 65 & 0.54 & 4.74 \\
& 25 & 0.23 & 11.40 \\
& 35 & 0.22 & 7.90 \\
& 45 & 0.41 & 8.84 \\
$10^{-4}$ & 55 & 0.75 & 14.90 \\
& 65 & 0.54 & 11.40 \\
& 25 & 0.35 & 21.90 \\
& 35 & 0.32 & 18.40 \\
& 45 & 0.80 & 20.80 \\
$10^{-3}$ & 55 & 0.82 & 38.00 \\
& 65 & 0.59 & 28.50 \\
& 25 & 0.60 & 45.90 \\
& 35 & 0.36 & 24.50 \\
& 45 & 0.85 & 25.40 \\
& 55 & 0.87 & 115.80 \\
& 65 & 0.67 & 62.30 \\
\hline
\end{tabular}


Table 7. Kinetic parameters for nickel electrodeposition on nickel in electrolyte solution containing $30 \mathrm{~g} \mathrm{~L}^{-1} \mathrm{H}_{3} \mathrm{BO}_{3}+5 \mathrm{~g} \mathrm{~L}^{-1} \mathrm{Ni}^{2+}$ in the absence and presence of different concentrations of expired drugs.

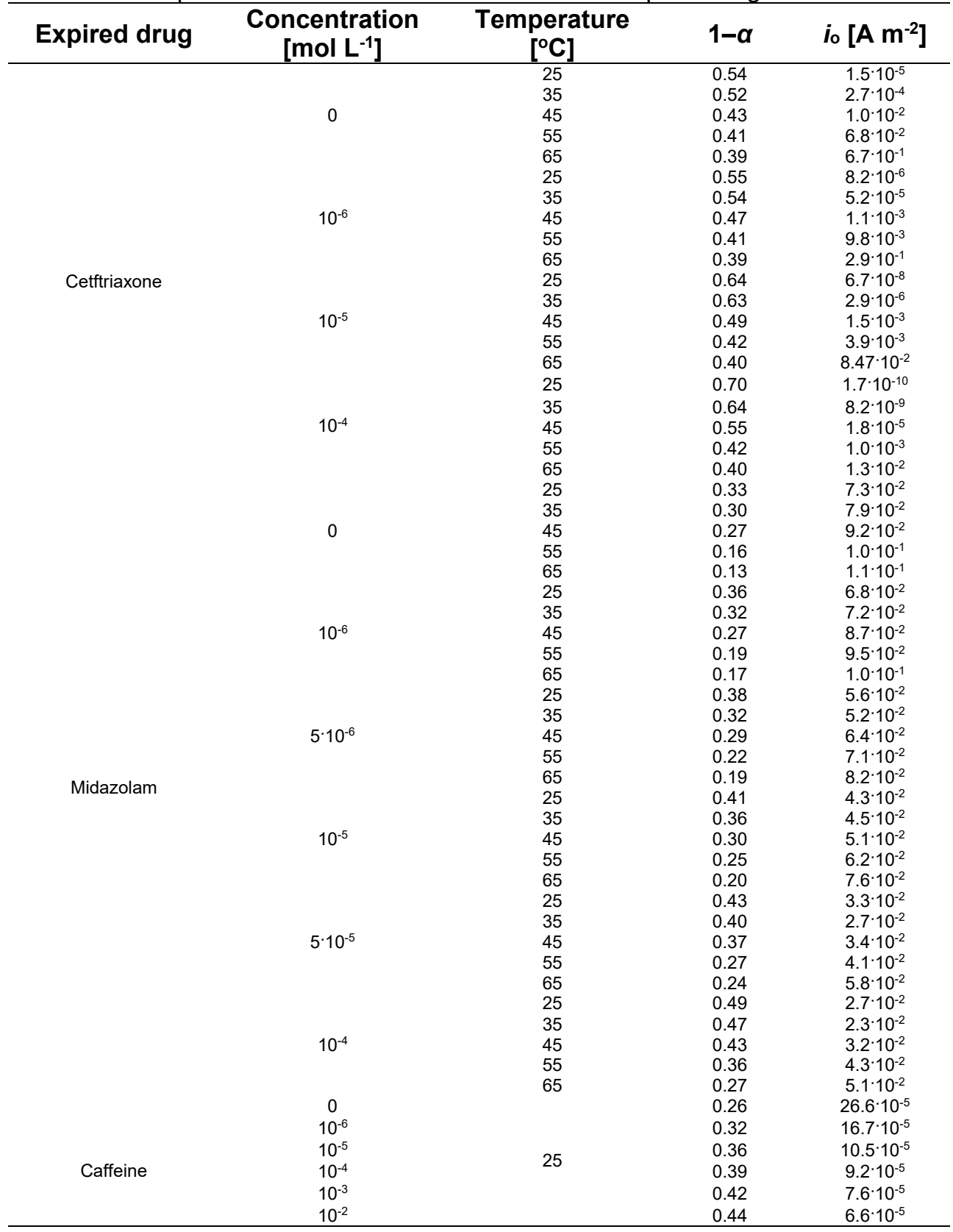


In both cases, the rate-determining step of the process is the monoelectronic charge transfer. The obtained results show both electrodeposition processes are influenced by the presence of a small concentration of expired drug in the electrolyte solution.

Temperature rise catalytic effect on nickel deposition is emphasized by the transfer coefficient 1- $\alpha$ decrease and increase of the exchange current density $i_{0}$.

The increase of the cathodic transfer coefficient with expired drug addition in the electrolyte solution is due to the shift of the reaction surface (inner Helmholtz plane) towards the bulk of solution [67]. This effect is diminished if the process takes place at high temperature.

For copper and nickel electrodeposition, using ceftriaxone from expired cefort drug as levelling agent, apparent activation energy was calculated from Arrhenius plots $[63,64]$. In has been observed an increase of the activation energy when ceftriaxone was added in the electrolyte solutions.

In copper deposition case, an increase from $30.8 \mathrm{KJ} \mathrm{mol}^{-1}$ (in $0.5 \mathrm{~mol}$ $\mathrm{L}^{-1} \mathrm{H}_{2} \mathrm{SO}_{4}+5 \mathrm{~g} \mathrm{~L}^{-1} \mathrm{Cu}^{2+}$ electrolyte solution) to $57.3 \mathrm{KJ} \mathrm{mol}^{-1}$ was noticed when $10^{-3} \mathrm{~mol} \mathrm{~L}^{-1}$ ceftriaxone was added, suggesting the process is inhibited by the presence of the expired drug. A similar effect was observed when ceftriaxone has been added in $30 \mathrm{~g} \mathrm{~L}^{-1} \mathrm{H}_{3} \mathrm{BO}_{3}+5 \mathrm{~g} \mathrm{~L}^{-1} \mathrm{Ni}^{2+}$ electrolyte solution; an increase from $27.2 \mathrm{KJ} \mathrm{mol}^{-1}$ to $48.6 \mathrm{KJ} \mathrm{mol}^{-1}$ has been seen at $10^{-4} \mathrm{~mol} \mathrm{~L}^{-1}$ ceftriaxone addition due to its adsorption onto the electrode surface.

For more precise characterization of the process occurring at interface during nickel electrodeposition and to observe ceftriaxone [64] and midazolam [65] influence on the process, electrochemical impedance spectroscopy (EIS) measurements have been done.

The shape of Nyquist spectra, a slightly suppressed semi-circle, indicates an electron transfer limiting process, characterised by the charge transfer resistance $\left(R_{\mathrm{ct}}\right)$.

A dependence between the diameter of the semi-circle and the concentration of expired drugs added in the electrolyte solution was observed. In both cases, the addition of expired drugs in the electrolyte solution leads to the increase of the semi-circle diameter and of $R_{\mathrm{ct}}$ values.

\section{CONCLUSIONS}

According to the literature data, active substances of drugs are good inhibitors for corrosion and metal deposition processes due to their molecular structure containing $\pi$ and/or lone pair electrons. In the last decade, starting with the papers of R. S. Abdel Hameed, studies on the inhibition properties 
have been focused on the expired drugs taking into account that, generally, fresh drugs are expensive. The report of US Food and Drug Administration, showing that $90 \%$ of the US Army drugs stock maintained their characteristics long time after expiration date, has stimulated the researches on the expired drugs as corrosion inhibitors and leveller agents in galvanotechnics.

Inhibition efficiencies over $90 \%$ have been reported especially for carbon steel in very aggressive media, like hydrochloric or sulphuric acid solutions. As well as, good efficiencies were obtained for anticorrosive protection of nickel, aluminum or copper.

There are few studies on the expired drugs used as levellers in galvanotechnics. Promising results were reported for copper and nickel electrodeposition.

Obtained results have proved that the expired drugs represents an interesting alternative to the recommended commercial substances used as corrosion inhibitors or levellers in the current technologies.

\section{ACKNOWLEDGMENTS}

This work was partially supported by University Politehnica Timisoara in the frame of PhD studies.

\section{REFERENCES}

1. A. Züttel, A. Borgschulte, L. Schlapbach, "Hydrogen as a Future Energy Carrier", Wiley-VCH Verlag, Weiheim, 2008, 156.

2. V.S. Bagotsky, "Fundamentals of Electrochemistry", Wiley Interscience, Hoboken, 2006, 321.

3. S. Srinivasan, "Fuel Cells - From Fundamentals to Applications", Springer, 2006, 209.

4. M.A. Kozak, J.R. Melton, S.A. Gernant, M.E. Snyder, Research in Social and Administrative Pharmacy, 2016, 12, 336.

5. A.Y.C. Tong, B.M. Peake, R. Braund, Environ. Int., 2011, 37, 292.

6. N. Vaszilcsin, V. Ordodi, A. Borza, Int. J. Pharm., 2012, 15, 241.

7. B. Mernari, H. El Attari, M. Traisnel, F. Bentiss, M. Lagrenee, Corros. Sci., 1998, 40, 391.

8. E.S.H. El Ashry, A. El Nemr, S.A. Esawyb, S. Ragab, Electrochim. Acta, 2006, 51, 3957.

9. G. Gece, Corros. Sci., 2011, 53, 3873. 
10. D.S. Chauhan, A.A. Sorour, M.A. Quraishi, Int. J. Chem. Pharm. Sci., 2016, 4, 680 .

11. R.S.A. Hameed, Al-Azhar Bull, Science, 2009, 20, 151.

12. R.S.A. Hameed, Phys. Chem. Ind. J., 2013, 8(4), 146.

13. F.H. Ali, T.A.M. Al-Shimiesawi, K.K. Hammud, S.A.A. Rahmman, "Carbon steel corrosion inhibition in acidic medium by expired drugs", The Fifth Scientific Conference of the College of Science University of Kerbala, 2017, 115.

14. R.S.A. Hameed, H.I. Al Shafey, A.H. Abu-Nawwas, Int. J. Electrochem. Sci., 2014, 9, 6006.

15. N.K. Gupta, C.S.A. Gopal, V. Srivastava, M.A. Quraishi, Int. J. Pharm. Chem. Anal., 2017, 4, 8.

16. P. Dohare, D.S. Chauhan, A.A. Sorour, M.A. Quraishi, Materials Discovery, 2017, 9, 30.

17. A.K. Singh, B. Chugh, S.K. Saha, P. Banerjee, E.E. Ebenso, S. Thakur, B. Pani, Results in Physics, 2019,14, 102383.

18. R.S.A. Hameed, Port. Electrochim. Acta, 2011, 29, 273.

19. R.A. Anaee, I.H.R. Tomi, M.H. Abdulmajeed, S.A. Naser, M.M. Kathem, J. Mol. Liq., 2019, 279, 594.

20. V.B. Terrones, C.M. Campos, M.R. Romo, J.M. Esparza Schutz, A. Dominguez, J. Uruchurtu Chavarin, Innovations Corr. Mat. Sci., 2015, 5, 31.

21. I.B. Obot, N.O. Obi-Egbedi, S.A. Umoren, Corr. Sci., 2009, 51, 1868.

22. A. Srinivasulu, P.K. Kasthuri, Oriental J. Chem., 2017, 33, 2616.

23. A.S. Fouda, M.A. El Morsi, T. El Mogy, Green Chem. Lett. Rev., 2017, 10, 336.

24. P. Geethamani, P.K. Kasthuri, Cogent Chem., 2015, 1, 1091558.

25. A.S. Fouda, H. Ibrahim, S. Rashwaan, A. El-Hossiany, R.M. Ahmed, Int. J. Electrochem. Sci., 2018, 13, 6327.

26. A.H.I. Al-Shafey, R.S.A. Hameed, F.A. Ali, A.E.S. Aboul-Magd, M. Salah, Int. J. Pharm. Sci. Rev. Res., 2014, 27, 146.

27. K.F. Khaled, Applied Surface Science, 2006, 252, 4120.

28. A. Samide, P. Ilea, A-C. Vladu, Int. J. Electrochem. Sci., 2017, 12, 5964.

29. I. Rotaru, S. Varvara, L. Gaina, L.M. Muresan, Appl. Surface Sci., 2014, 321, 188.

30. D.A. Duca, M.L. Dan, N. Vaszilcsin, Materials Sci. Eng., 2018, 416, 012043.

31. A.S. Fouda, W.M. Mahmoud, K.M.A. Elawaye, Prot. Met. Phys. Chem. Surf., 2017, 53, 139.

32. P. Dohare, D.S. Chauhan and M.A. Quraishi, Int. J. Corr. Scale Inh., 2018, 7, 25.

33. N. Raghavendra, J. Chem. Pharm. Res., 2018, 10,1.

34. P. Singh, D.S. Chauhan, S.S. Chauhan, G. Singh, M.A. Quraishi, J. Mol. Liq., 2019, 286, 110903.

35. A.K. Singh, A.K. Pandey, P. Banerjee, S.K. Saha, B. Chugh, S. Thakur, B. Pani, P. Chaubey, G. Singh, J. Environ. Chem. Eng., 2019, 7, 102971.

36. S. Dahiya, N. Saini, N. Dahiya, H. Lgaz, R. Salghi, S. Jodeh, S. Lata, Port. Electrochim. Acta, 2018, 36, 213.

37. P. Singh, D.S. Chauhan, K. Srivastava, V. Srivastava, M.A. Quraishi, Int. J. Ind. Chem., 2017, 8, 363. 
38. V. Rajeswari, K. Devarayan, P. Viswanathamurthi, Res. Chem. Intermed., 2017, 43, 3893.

39. N. Raghavendra, L.V. Hublikar, A. S. Bhinge, P.J. Ganiger, Int. J. Res. Advent Technol., 2019, 7, 675.

40. N. Raghavendra, L.V. Hublikar, P.J. Ganiger and A.S Bhinge, Int. J. Green Herbal Chem. - Section A, 2019, 8, 610.

41. N. Raghavendra, Sci. Lett., 2019, 7, 26.

42. N. Raghavendra, Int. J. Chem. Mat. Res., 2018, 6, 1.

43. N.O. Eddy, S.R. Stoyanov. E.E. Ebenso, Int. J. Electrochem. Sci., 2010, 5, 112.

44. M. Bobina, A. Kellenberger, J.P. Millet, C. Muntean, Corr. Sci., 2013, 69, 389.

45. A. Samide, B. Tutunaru, Central Eur. J. Chem., 2014,12, 901.

46. N. Raghavendra, Chem. Africa, 2019, doi.org/10.1007/s42250-019-00061-2.

47. A.S. Fouda, W.M. Mahmoud, H.A.A. Mageed, J. Bio.Tribo. Corr., 2016, 2, 7.

48. L.P. Chaudhari, S.N. Patel, J. Bio Tribo Corr., 2019, 5, 20.

49. L. Herrag, B. Hammouti, S. Elkadiri, A. Aouniti, C. Jama, H. Verzin, F. Bentiss, Corr. Sci., 2010, 52, 3042.

50. J. Aljourani, K. Raeissi, M.A. Golozar, Corr. Sci., 2009, 51, 1836.

51. P. Geethamani, M. Narmatha, R. Dhanalakshmi, S. Aejitha, P.K. Kasthuri, J. Bio Tribo Corr., 2019, 5, 16.

52. A. Kumar, S. Bashir, Russian J. Appl. Chem., 2016, 89, 1158.

53. A.S. Fouda, A. M. El-Azaly, Zastita Materijala, 2018, 59, 226.

54. N. Raghavendra, J. Sci. Eng.Technol., 2018, 6, 35.

55. M.M. Motawea, H.S. Gadow, A.S. Fouda, Global J. Res. Eng. C Chemical Eng., 2016, 16, 1.

56. R.S. Nathiya, S. Perumal, V. Murugesan, V. Raj, J. Bio Tribo Corr., 2018, 4, 4.

57. K. Rezaei Jahromi, and C. Dehghanian, Int. J. Curr. Res., 2017, 9, 44630.

58. R.S. Abdel Hameed, E.A. Ismail, A.H. Abu-Nawwas, and H.I. Al-Shafey, Int. J. Electrochem. Sci., 2015, 10, 2098.

59. M. Dan, N. Vaszilcsin, M. Labosel, B. Pancan, Chem. Bull. "POLITEHNICA" Univ. Timisoara, 2014, 59 (73), 13.

60. D.A. Duca, M.L. Dan, N. Vaszilcsin, Adv. Eng. Forum, 2018, 27, 74.

61. N. Raghavendra, L.V.Hublikar, A.S.Bhinge, P.J.Ganiger, Int. J. Res. Appl. Sci. Eng.Technol., 2019, 7, 2289.

62. N. Raghavendra, J. Adv. Electrochem., 2019, 5, 177.

63. D.A. Duca, M.L. Dan, N. Vaszilcsin, Annals Univ. Oradea Environ. Protect., 2016, $27,229$.

64. D.A. Duca, M.L. Dan, N. Vaszilcsin, Chem. J. Moldova, 2017, 12, 87.

65. D.A. Duca, N. Vaszilcsin, M.L. Dan, SGEM Conference Proceedings, 2016, 4, 105.

66. D.A. Duca, M.L. Dan, N. Vaszilcsin, Annals Univ. Oradea Environ. Protect., 2015, $15,177$.

67. J. O’M. Bockris, A.K.N. Reddy, M.E. Gamboa-Aldeco, "Modern Electrochemistry", Vol. 2A, Second edition, Kluwer Academic Publishers, New York, 2000, 1479. 